\title{
MANAJEMEN MUTU MADRASAH DINIYAH DI ERA KONTEMPORER
}

\author{
Nur Jannah \\ Dosen Tetap Yayasan IAI Al Falah As Sunniyyah Kencong Jember
}

\begin{abstract}
Madrasah Diniyah is one of the very unique Islamic Education institutions, where its existence is an asset that is urgently needed in this contemporary era, the rapid development of technology and communication is not only positive but also affects the moral and spiritual crisis faced by generations current generation of millennials. The existence of the Diniyah Madrasah is expected to be able to make a positive contribution in overcoming the problem, but it is only necessary to implement quality management in the Diniyah Madrasah because in reality there are still many shortcomings in the Islamic Early Madrasas, still impressed as they are and traditional Therefore, it is necessary to improve the quality of the Madrasah Diniyah in this contemporary era. With more professional management, the use of strategies that prioritize creativity is in accordance with the state of society's culture and needs to be supported by various factors, both internal and external so as to provide educational output in the form of generations of millennials who are virtuous, intellectual, skilled and charitable so can contribute to the glory of Islamic civilization, the nation and the State of Indonesia in the present and future
\end{abstract}

Keyword: Quality Management, Madrasa Diniyah

\section{PENDAHULUAN}

Dalam pandangan Islam ilmu pengetahuan dan tekhnologi itu bertolak dari Iman, Islam dan Ihsan yang dikembangkan justru untuk menambah keimanan dan memberikan kemaslahatan bagi kehidupan manusia, namun sayangnya kemajuan tekhnologi yang terjadi saat ini malah membuat manusia khawatir dan takut akan dampak negatifnya, bahkan ada pula yang sudah merasakan langsung akibatnya, sehingga mempengaruhi kehidupannya baik kehidupan materil maupun spirituilnya.

Dalam dunia pendidikan perkembangan tekhnologi dan komunikasi dewasa ini memberikan dampak yang sangat besar terhadap input, proses maupun output pendidikan, hanya saja perkembangan tekhnologi dan komunikasi ini justru berbanding terbalik dengan menurunnya nilai-nilai moral, spiritual peserta didik, padahal tuntutan zaman bukan hanya mengandalkan kemampuan dan

Falasifa, Vol. 9 Nomor 2 September 2018 | 61 
kecanggihan tekhnologi saja, orang tua yang merasa bertanggung jawab terhadap pendidikan putra-putrinya membutuhkan nilai-nilai Islami dan bekal akhlak untuk mereka, demi memenuhi kebutuhan pendidikan tersebut orang tua mempercayakan pada Madrasah Diniyah sebagai salah satu lembaga pendidikan Islam yang dianggap mampu memenuhi harapannya.

Eksistensi Madrasah Diniyah di Indonesia memang sangat unik karena selain dikelola apaadanya, masih bersifat orisinil dan tradisional namun Madrasah Diniyah ini ternyata merupakan salah satu asset yang sangat dibutuhkan dan perlu dipertahankan eksistensinya.Adanya lembaga pendidikan Islam seperti Madrasah Diniyah ini ternyata mampu memberikan kontribusi dalam mencerdaskan kehidupan bangsa, mengembangkan kehidupan moral dan agama. Salah satu contoh tokoh besar yang lahir dari latar belakang madrasah adalah Abdurrahman Wahid atau sering dipanggil Gus Dur yang merupakan salah satu mantan presiden Republik Indonesia, dimananama besarnya dianggap sangat berpengaruh terhadap pemikiran dan kehidupan masyarakat bangsa ini.

Madrasah sendiri dibentuk dengan adanya keputusan Menteri Agama pada tahun 1964, dimana dalam madrasah ini materi yang diajarkan seluruhnya merupakan ilmu-ilmu agama.Madrasah bisa dikatakan sekolah tambahan bagi siswa yang bersekolah di sekolah umum, bagi mereka yang merasa kurang dan menginginkan tambahan pendidikan agama bisa bersekolah di Madrasah. ${ }^{1}$ Bagi sebagian kalangan masyarakat, madrasah diniyah merupakan salah satu lembaga pendidikan non formal yang dapat membantu mereka dalam membekali akhlak yang terpuji bagi anak didiknya.

Selain keputusan di atas Madrasah Diniyah juga diatur dalam peraturan Departemen Agama, pertamaMadrasah Diniyah adalah lembaga pendidikan dan pengajaran secara klasikal dalam pengetahuan Agama Islam, sedikitnya berjumlah 10 orang atau lebih diantara anak-anak usia 7 sampai 20 tahun.Kedua, pendidikan dan pengajaran pada Madrasah Diniyah bertujuan memberikan tambahan dan pendalaman pengetahuan agama Islam kepada para pelajar yang merasa kurang menerima pelajaran agama di sekolah umum.Ketiga, Madrasah Diniyah mempunyai tiga tingkatan, yakni Madrasah Diniyah Awwaliyah, Diniyah Wustho dan Diniyah Ulya. ${ }^{2}$

Dalam peraturan pemerintah No. 55 tahun 2007 pasal 15 juga dijelaskan

${ }^{1}$ Haidar Putra Daulay. Historisitas dan Eksistensi: Pesantren Sekolah dan Madrasah. (Yogyakarta: PT Tiara Wacana, 2001), 61

${ }^{2}$ Departemen Agama. Draf penyelenggaraan Madrasah Diniyah (Jakarta: Direktorat Pendidikan Diniyah dan Pesantren ditjen Pendidikan Islam Depag RI. 2006), 3

62 | FaLASIFA, Vol. 9 Nomor 2 September 2018 
bahwa madrasah diniyah atau pendidikan diniyah formal menyelenggarakan pendidikan ilmu-ilmu yang bersumber dari ajaran agama Islam pada jenjang anak usia dini, pendidikan dasar, pendidikan menengah dan pendidikan tinggi. ${ }^{3}$

Dari beberapa aturan-aturan diatas menunjukkan bahwa adanya keterlibatan pemerintah dalam pengelolaan Pendidikan Keagaamaan Islam, hanya saja pada realitasnya eksistensi Madrasah Diniyah masih banyak sekali kekurangan terutama dalam hal manajemen mutu pengelolaan madrasah diniyah yang selama ini terkesan apa adanya tanpa ada upaya perbaikan-perbaikan. Meski selama ini penerapan manajemen mutu lebih banyak diterapkan di lembaga-lembaga pendidikan formal dan jarang sekali diterapkan di lembaga pendidikan madrasah diniyah, karena itu perlu adanya implementasi manajemen mutu pada madrasah diniyah, meskipun madrasah diniyah hanyalah dianggap lembaga pendidikan 'kedua', namun memiliki tingkat signifikansi tertentu, terutama dalam upaya pembentukan karakter pribadi para siswa yang berakhlaq mulia dan uniknya sistem pendidikan madrasah yang berbasiskan pengetahuan agama ini tanpa harus tercerabut dari lembaga pendidikan nasional lainnya yang lebih modern dan tetap eksis dalam ruang pendidikan di Indonesia ke depannya.

Selain berdasarkan pada nilai-nilai Islami yang bersumber pada Al Qu'ran, sunnah dan ijtihad Pendidikan Islam di era kontemporer ini harus berorientasi pada kemajuan ilmu pengetahuan dan tekhnologi serta mampu memenuhi kebutuhan dan tuntutan masyarakat dengan memberikan output pendidikan yang mampu mencetak generasi millennials yang berakblakul karimah, berilmu pengetahuan luas dan mampu beramal sholih, sehingga mampu bersaing dan mempunyai nilai lebih dari lembaga pendidikan formal lainnya.

\section{PEMBAHASAN}

\section{Manajemen Mutu Pendidikan}

Pendidikan merupakan salah satu jalan untuk menuju era kontemporer, pendidikan yang dibutuhkan di era ini tentu pendidikan yang bermutu, meskipun dalam konsep mutu pendidikan banyak sekali perbedaan pendapat untuk menentukan indikator-indikator yang dipakai untuk mengukur mutu, walaupun belum ada kesamaan pandangan tentang mutu, dalam tulisan ini akan dikemukakan beberapa batasan tentang mutu yang dapat dipakai sebagai acuan dalam pembahasan selanjutnya tentang manajemen mutu pengelolaan madrasah

\footnotetext{
${ }^{3}$ Raharjo.Pemberdayaan Madrasah Diniyah Dalam Mewujudkan Pendidikan Berbasis Masyarakat di Madrasah Diniyah "Miftahul Huda" (Kabupaten Kendal. Semarang: IAIN Walisongo. 2013), 20
}

FaLASIFA, Vol. 9 Nomor 2 September 2018 | 63 
diniyah.

Mutu, menurut Edward Sallis dapat dipandang sebagai sebuah konsep yang absolute sekaligus relatif.Mutu dalam percakapan sehari-hari sebagian besar dipahami sebagai sesuatu yang absolut, misalnya restoran yang mahal dan mobilmobil yang mewah. Sebagai suatu konsep yang absolut, mutu sama halnya dengan sifat baik, cantik, dan benar; merupkan suatu idealisme yang tidak dapat dikompromikan. Dalam definisi yang absolut, sesuatu yang bermutu merupakan bagian dari standar yang sangat tinggi dan tidak dapat diungguli. ${ }^{4}$

Sedangkan mutu yang relatif, mutu dipandang sebagai suatu yang melekat pada sebuah produk yang sesuai dengan kebutuhan pelanggannya. Untuk itu dalam definisi relatif ini produk atau layanan akan dianggap bermutu, bukan karena ia mahal dan eksklusif, tetapi ia memiliki nilai misalnya keaslian produk, wajar dan familiar. ${ }^{5}$

Selanjutnya, mutu, sebagaimana diinterpretasikan oleh ISO 9000, merupakan perpaduan antara sifat-sifat dan karakteristik yang menentukan sampai seberapa jauh keluaran/mutu barang/lulusan dapat memenuhi kebutuhan pembeli/pemakai lulusan. ${ }^{6}$ Pertanyaan sampai seberapa jauh lulusan dapat memenuhi kebutuhan pemakai lulusan, dijawab oleh pemakai lulusan sendiri bukan oleh lembaga pendidikan yang meluluskannya.

Pendidikan yang bermutu tidak hanya bisa dilihat dari kualitas lulusannya saja, tetapi juga mencakup bagaimana lembaga pendidikan mampu memenuhi kebutuhan pelanggan sesuai dengan standar mutu yang berlaku. Pelanggan dalam hal ini ada dua yang pertama, pelanggan internal (tenaga kependidikan), kedua pelangganeksternal (peserta didik, orangtua, masyarakat dan pemakai lulusan). ${ }^{7}$

Berdasarkan uraian di atas konsep mutu yang dimaksud dalam tulisan ini adalah konsep mutu relatifsesuai yang dipaparkan oleh Edward Sallis. Artinya dalam proses pengelolaan madrasah tidak perlu harus mengeluarkan biaya maupun tenaga ekstra untuk mencapai mutu yang bernilai mahal dan eksklusif, tetapi ia perlu menunjukkan keasliannya dan kewajarannya serta keefektifannya sesuai dengan tuntutan dan kebutuhan masyarakat yang hidup di era millennials.

Adapun beberapa prinsip mutu yang dinilai dan diyakini memiliki kekuatan

\footnotetext{
${ }^{4}$ Edward Sallis.Total Quality Management in Education.(Jogjakarta; Ircisod, 2006), 51-52

${ }^{5}$ Ibid, 53

6 Bambang H. Hadiwiarjo,\& Sulistijarningsih Wibisono. Memasuki Pasar Internasional Dengan ISO 9000. (Jakarta : Ghalia Indonesia, 2000)

${ }^{7}$ Mulyasa. 2009. Menjadi Kepala Sekolah Profesional. (Bandung: Remaja Rosdakarya, 2009), 225-226
}

64 | FaLASIFA, Vol. 9 Nomor 2 September 2018 
untuk mewujudkan mutu.Dalam hal ini para ahli dan organisasi mencoba merumuskan prinsip-prinsip yang dianggap tepat untuk mewujudkan mutu dalam organuisasi. Menurut versi ISO ada delapan prinsip mutu, yaitu: ${ }^{8}$

1. Berorientasi pada pelanggan

2. Kepemimpinan

3. Keterlibatan masyarakat

4. Pendekatan proses

5. Menggunakan pendekatan system pada manajemen

6. Perbaikan secara berkelanjutan

7. Pendekatan faktual dalam pembuatan keputusan.

8. Memiliki Hubungan yang saling menguntungkan dengan supplier.

Prinsip-prinsip diatas dapat dijadikan sebagai panduan dalam peningkatan mutu pada madrasah Diniyah dengan menerapkan semua prinsip-prinsip yang ada dalam manajemen Madrasah Diniyah.

\section{Madrasah Diniyah di Era Kontemporer}

a. Madrasah Diniyah

Dalam bahasa Arab kata Madrasah merupakan bentuk dari kata keterangan tempat yang berasal dari kata "darasa".Secara harfiah "Madrasah dapat diartikan sebagai tempat belajar bagi para pelajar atau tempat untuk memberikan pelajaran. ${ }^{9}$ Sedangkan dalam struktur bahasa Arab kata Madrasah diniyah terdiri dari dua kata Madrasah dan al-din. Kata Madrasah sendiri berasal dari kata "darasa" yang artinya belajar, jadi Madrasah dapat dimaknai dengan belajar, sedangkan kata "al-din" dimaknai dengan keagamaan. Jadi, madrasah diniyah dapat diartikan sebagai tempat belajar masalah keagamaan yang dalam hal ini adalah agama Islam. ${ }^{10}$

Secara istlah Madrasah diniyah merupakan satu lembaga pendidikan keagamaan pada jalur luar sekolah yang diharapkan mampu secara terus menerus memberikan pendidikan agama Islam kepada anak didik yang tidak terpenuhi pada jalur sekolah yang diberikan melalui sistem klasikal serta menerapkan jenjang pendidikan. ${ }^{11}$ Atau Madrasah diniyah sering disebut sebagai lembaga pendidikan

${ }^{8}$ Deni Koswara. Manajemen Pendidikan. (Bandung: Alfabeta. 2014), 295

${ }^{9}$ A.W. Munawwir.Kamus Arab Indonesia.(Surabaya: Pustaka Progresif. 2002), 300

10 Haedari Amin. Dkk. Peningkatan mutu terpadu Pesantren dan Madrasah Diniyah.(Jakarta: Diva Pustaka. 2004), 14

${ }^{11}$ Departemen Agama RI II. Pedoman Penyelenggaraan dan Pembinaan Madrasah Diniyah. (Jakarta: Depag. 2002), 7 
Islam yang hanya mengajarkan ilmu-llmu diniyah atau agama. ${ }^{12}$

Madrasah memiliki penekanan sebagai suatu lembaga yang mengajarkan ilmu-ilmu keislaman, karena pada prinsipnya madrasah merupakan kelanjutan dari sistem pesantren. ${ }^{13}$ Dengan kata lain madrasah diniyah merupakan lembaga pendidikan yang semua mata pelajarannya bersumber dari ilmu-ilmu agama, seperti fiqih, tafsir, tauhid, dan ilmu-ilmu agama yang lain. ${ }^{14}$

Sementara itu menurut Karel A. Steenbrink antaramadrasah dan sekolah itu berbeda dan memiliki ciri masing-masing. ${ }^{15}$ Secara institusi madrasah memiliki varian yang banyak sekali. Sebutlah misalnya madrasah diniyah sore, diniyah pesantren, diniyah salafiyah Ula-Wustha-Ulya, diniyah mi'allimien-muallimat, kulliyatul mu'allimien al-Islamiyah, dan sebagainya, begitu pula institusi yang menyelenggarakan pendidikan madrasah diniyah juga bermacam-macam, seperti yang diselenggarakan oleh organisasi masyarakat, lembaga pendidikan formal, dan pesantren. Karenanya secara fungsional pun madrasah diniyah beragam: ada yang bersifat supplement, complement, dan samplement ${ }^{16}$.

Madrasah diniyah yang masuk kategori supplement adalah diniyah sore dan diniyah pesantren yang hanya dilangsungkan dalam waktu tertentu (sore hari atau malam hari setelah magrib) di tengah-tengah rutinitas kegiatan pesantren. Madrasah diniyah ini ada yang diselenggarakan secara formal (memiliki kurikulum, memakai evaluasi, memiliki jenjang 6-3-3, dsb,) dan nonformal.Pendidikan diniyah ini diselenggarakan dalam rangka melengkapi pengetahuan agama murid/santri.

Adapun madrasah diniyah complement adalah model pendidikan keagamaan yang diadopsi sebagai satu kesatuan system pendidikan formal. Jenis pendidikan diniyah ini sekarang banyak diterapkan di daerah, bahkan telah menjadi ketetapan pemerintah daerah seperti di Indramayu, Tasikmalaya, Cianjur, Bukit Tinggi dan sebagainya.Model pendidikan ini ada yang bersifat formal dan non-formal.

Sementara madrasah diniyah samplement merupakan madrasah diniyah, baik formal maupun non-formal, yang betul-betul menyelenggarakan pendidikan

\footnotetext{
${ }^{12}$ Ridwan Nasir. Mencari Tipologi Format Pendidikan Ideal Pondok Pesantren di Tengah Arus Perubahan (cetakan pertama, Yogyakarta: Pustaka Belajar. 2005), 95

${ }^{13}$ Haidar Putra Daulay. Sejarah Pertumbuban dan Pembaharnan Pendidikan Islam Indonesia, Jakarta: Kencana Predana Media Group. 2009), 94

${ }^{14}$ HaedariAmin, dkk, 39

${ }^{15}$ Dalam Fatah syukur NC, Sejarah Pendidikan Islam, (Semarang: Pustaka Rizki Putra, 2012), 118

${ }^{16}$ M. Ishom el Saha. Arah Pengembangan Madrasah Diniyah di Indonesia. (Jurnal Mihrab, Edisi I, th. III Oktober 2005), 84.
}

66 | FaLASIFA, Vol. 9 Nomor 2 September 2018 
diniyah layaknya pendidikan sekolah/madrasah formal.Kebanyakan diniyah ini diselenggarakan di pesantren seperti Pesantren Gontor dan lainnya.Selain itu juga ada sedikit yang diselenggarakan di luar pesantren, seperti diniyah mu'allimat rahman el yumusy di Sumatera Barat.

b. Realitas dan Tantangan Madrasah Diniyah

Madrasah diniyah saat ini dalam sistem pendidikan nasional tergolong lembaga pendidikan non-formal. ${ }^{17}$ Namun posisinya manjadi sangat strategis karena kemunculannya atas inisiatif dari pengelolaan masyarakat (bottom up) sehingga sangat disesuaikan dengan kondisi dan ekspektasi peserta didik dan masyarakat di mana madrasah tersebut berada. Justru di sinilah madrasah diniyah mampu meletakkan perannya secara lebih maksimal, karena ia akan dapat bergerak lebih fleksibel tanpa dipengaruhi oleh pihak-pihak luar serta tetap berpijak pada kebutuhan murni dari hasil ekspektasi masyarakat dan pelajar setempat yang dipersiapkan untuk mampu menjawab kebutuhan masyarakat dimasa depan, di mana moralitas dan agama menjadi sesuatu yang langka. Dengan demikian maka tidak heran jika kemudian model pembelajaran dan pengelolaannya cukup beragam sesuai dengan kultur dan pengetahuan masyarakat setempat, sehingga mengesankan orisinalitas dan kealamian produk pembelajaran asli Indonesia sebagai mana pesantren-pesantren yang keberadaannya lebih dahulu menjamur di seantero wilayah Indonesia.

Namun demikian, seiring dengan laju perkembangan zaman, madrasah diniyah pun tak mungkin lagi menghindar dari tantangan yang bermunculan. Dunia industri yang telah merubah tuntutan kebutuhan masyarakat akan dunia pendidikan, mau tidak mau memaksa para praktisi di dunia madrasah khususnya madrasah diniyah untuk merumuskan ulang tentang konsep pendidikan yang selama ini mereka pegang. Ditambah lagi munculnya model-model pendidikan baru, yang mau tidak mau menjadi pesaing yang cukup berat bagi madrasah diniyah. Jika hanya terpaku pada sistem lama, pelan tapi pasti madrasah akan kehilangan peminatnya. Pada titik ini sudah semestinya para praktisi harus membuat perumusan ulang, untuk lebih menonjolkan kekhasannya dari model

\footnotetext{
${ }^{17}$ Perlu adanya kajian ulang terhadap istilah formal dan non-formal di sini, karena banyak lembaga pendidikan yang tergolong non-formal dalam system pendidikan Indonesia justru dalam praktik sistem pendidikannya dilaksanakan secara formal. Jika pengertian status formalitas itu diukur atau dinilai dari adanya gedung dan ruang permanen, kurikulum tetap, konsistensi perjenjangan, evaluasi beraturan, kompetensi pengajar, dan menganut system manajemen pendidikan, maka saat ini banyak madrasah diniyah baik supplement, complementmaupun samplement yang diatur secara formal dan mau tidak mau diakui sebagai lembaga yang berstatus formal.
}

FALASIFA, Vol. 9 Nomor 2 September 2018 | 67 
pendidikan lain. Dengan demikian hal ini nantinya bukan berarti melakukan 'ikutikutan' secara buta apa yang telah dikembangkan oleh satuan pendidikan lainnya. Tetapi lebih mengedepankan kemandirian dan kreatifitas pengelola madrasah diniyah dalam upaya peningkatan mutu pendidikannya kearah yang lebih baik sebagai bukti tanggung jawab dalam menghadapi tantangan zaman ke depan.

Menurut Malik Fadjar beberapa hal penting yang perlu mendapatkan prioritas perhatian pengembangan madrasah diniyah kedepan adalah kualitas dan kuantitas guru yang belum memadai, sarana fisik atau fasilitas pendidikan yang minim, manajemen non professional, jumlah murid yang sedikit dan kebanyakan dari kalangan menengah ke bawah ${ }^{18}$. Madrasah menjadi sangat sulit menjadi center of excellence dan mampu berkompetisi dengan lembaga-lembaga pendidikan lainnya jika tidak mempunyai manajemen yang baik. ${ }^{19}$

Selain itu salah satu penyebab makin menurunnya mutu persekolahan di Indonesia adalah kurang profesionalnya kepala sekolah sebagai manajer pendidikan ditingkat lapangan.Kepala sekolah sebagai seorang pengendali sekaligus figur yang bertanggung jawab untuk menggerakkan kesadaran semua pihak, strategi pembelajaran, pengkondisian lingkungan belajar dan sebagainya. Ketika unsur-unsur tersebut tidak berkembang maka kepala sekolah yang akan lebih dahulu dipersalahkan. Apabila kepala sekolah telah berupaya maksimal untuk mewujudkan mutu pendidikan dengan berbagai cara yang rasional. Sementara hasilnya masih dianggap rendah maka ada beberapa faktor lain yang dapat menghambat pencapaian mutu pendidikan tersebut. ${ }^{20}$

Pada hakikatnya penyelenggaraan manajemen sistem pendidikan di madrasah sama dengan lembaga pendidikan formal. ${ }^{21}$ Hanya Ijazah Madrasah ini tidak memiliki civil effect, karena itu orang tua tidak terlalu memikirkannya. ${ }^{22}$ Meskipun ijazah madrasah diniyah dianggap tidak memberikan efek apapun, namun pada kenyataannya kehadiran madrasah diniyah masih dibutuhkan oleh sebagian masyarakat yang mementingkan nilai-nilai Islami dalam pendidikan anak-anaknya, selain itu madrasah diniyah juga dianggap mampu memberikan bekal akhlak yang terpuji bagi para lulusannya.

${ }^{18}$ Malik Fadjar. Madrasah \& Tantangan Modernitas, (Mizan:Bandung, 1999), 7

${ }^{19}$ Suwito.Sejarah Sosial Pendidikan Islam, (Jakarta: kencana Predana Media Group. 2008), 295

${ }^{20}$ Qomar, Mujamil. Manajemen Pendidikan Islam.(Jakarta: Erlangga. 2007), 204

${ }^{21}$ Fatah yasin.Dimensi-dimensi Pendidikan Islam,(Malang: Sukses Offset. 2008), 268

${ }^{22}$ Ridwan Nasir, 96

68 | ҒALASIFA, Vol. 9 Nomor 2 September 2018 
Strategi Implementasi Manajemen Mutu Pengelolaan Madrasah di Era Kontemporer

Dalam implementasi Manajemen mutu pengelolaan Madrasah Diniyah secara garis besar samaseperti halnya strategi dalam manajemen mutu berbasis sekolah atau madrasah yang mencakup penyiapan konsep, pengelompokan madrasah, dan pentahapan implementasi beserta perangkatnya. ${ }^{23}$

a. Penyiapan Konsep

Saat ini semua operasional pendidikan telah diotonomikan kepada setiap lembaga pendidikan dengan dikukuhkannya manajemen berbasis sekolah atau madrasah, hal itu dimaksudkan agar proses pendidikan nantinya tidak cenderung kaku, membosankan dan merasa terpasung kepada aturan kebijakan yang serba terpusat. Namun demikian agar implementasi manajemen berbasis madrasah tersebut berjalan secara baik maka setidaknya ada enam hal yang perlu diperhatikan dalam penyaiapan konsep MBM; 1) pemilihan kepala madrasah dan pendidik professional; 2) bentuk partisipasi masyarakat dan orang tua (komite madrasah); 3) pendanaan madrasah; 4) Kualitas stakeholders pendidikan; 5) political will pemerintah pada berbagai lapisan.

b. Pengelompokan Madrasah

Agar manajemen berbasis madrasah dapat diimplimentasikan secara optimal, perlu adanya pengelompokan madrasah berdasarkan tingkat kemampuan manajemen masing-masing. Dalam hal ini sedikitnya akan ditemui tiga kategori madrasah, yaitu baik, sedang, dan kurang, yang tersebar di lokasi-lokasi maju, sedang, dan ketinggalan.Pengelompokan madrasah tersebut dimaksudkan untuk menunjukkan bahwa tingkat kemampuan manajemen madrasah untuk mengimplimentasikan MBM berbeda antara satu dengan lainnya.

c. Pentahapan Implementasi

Implementasi manajemen berbasis madrasah tidak mungkin dilakukan sekaligus, tetapi perlu pentahapan sesuai dengan kondisi sosial masyarakat serta mempertimbangkan faktor geografis, demografis, budaya setempat dan potensi dasar madrasah.Setidaknya tahapan implementasi MBM meliputi empat tahapan yaitu, sosialisasi, piloting, pelaksanaan, dan diseminasi.

Tahap sosialisasi perlu dilakukan melalui berbagai cara dan berbagai macam alat, hal ini mengingat luasnya wilayah nusantara, selain juga untuk mengantisipasi sulitnya masyarakat menerima perubahan. Tahap piloting merupakan tahap ujicoba agar penerapan konsep manajemen berbasis madrasah tidak mengandung resiko. Tahap pelaksanaan merupakan tahap untuk melakukan berbagai diskusi, curah

\footnotetext{
${ }^{23}$ Dirjen Kelembagaan Agama Islam Depag.Manajemen Merbasis Madrasah, 13
}

FaLASIFA, Vol. 9 Nomor 2 September 2018 | 69 
pendapat atau lainnya antara kelompok kerja MBM dengan berbagai unsur terkait, yakni guru, kepala madrasah, pengawas, tokoh agama, pengusaha, dan para akademisi.

\section{d. Perangkat Implementasi MBM}

Dalam implementasi MBM, madrasah memerlukan pedoman-pedoman pendukung untuk menjamin terlaksananya manajemen yang mengakomodasi kepentingan otonomi madrasah, kebijakan pemerintah, dan partisipasi masyarakat.Dalam hal ini, diperlukan seperangkat peraturan dan pedomanpedoman umum yang dapat dipakai sebagai pedoman perencanaan, monitoring, dan evaluasi, serta laporan pelaksanaan.

\section{Kerangka Konseptual Pengelolaan Madrasah Diniyah yang Efektif}

Madrasah diniyah yang efektif adalah madrasah yang mempunyai visi, misi, tujuan, sasaran, peningkatan mutu dan menghasilkan alumni yang unggul dan bisa diandalkan.Untuk itu sudah saatnya madrasah diniyah tidak hanya menekankan pendidikannya pada pembentukan sifat dan watak atau karakter tertentu yang dianggap ideal, dengan menafikan bidang-bidang lainnya seperti penguasaan ilmu pengetahuan, teknologi dan lain-lain ${ }^{24}$.

Sementara itu menurut Ghulam Farid Malik ada beberapa komponen penting untuk membangun madrasah yang efektif ;

1. Madrasah yang efektif mempunyai filosofi umum yang bersifat humanis, ideologi, nilai-nilai dan juga misi

2. Madrasah yang efektif memiliki sasaran dan tujuan yang jelas, kurikulum, bahasa, simbol dan metamor kepahlawanan, struktur organisasi fungsional dengan peran dan tanggung jawabyang ditentukan dengan baik.

3. Madrasah yang efektif menetapkan baku yang tinggi untuk akademis, demikian juga mutu atau etika Islami, mengajarkan kurikulum nasional yang bukan agama, menunjukkan logo keislaman dan nasionalisme dalam ritual juga kegiatan lain.

4. Adanya fasilitas belajar yang cukup memadai, SDM yang bertanggung jawabdan motivasi lingkungan belajar mengajar.

5. Madrasah juga mempertahankan upacara dan ritualdengan tradisi Islam dan nasional, mempunyai proses belajar mengajar yang efektif, supervise, prosedur operasional, peraturan, penghargaan, sangsi, partisipasi, dan dukungan orangtua juga masyarakat.

6. Output yang diperoleh juga memenuhi standar yang tinggi, baik akademis

${ }^{24}$ Amin Haedari, dkk, 29

70 | FaLASIFA, Vol. 9 Nomor 2 September 2018 
maupun perilaku, pengetahuan ketrampilan dan perilaku diperoleh siswa sejalan dengan misi, nilai-nilai Islam, perbaikan lingkungan masyarakat, dll..$^{25}$

Dengan kata lain madrasah diniyah yang efektif mampu melahirkan generasi yang tidak gagap dalam menghadapi dunia luar yang penuh dengan persaingan. Untuk itu madrasah diniyah dalam upaya pengelolaanya ke arah yang lebih baik hendaknya terlebih dahulu melaksanakan beberapa hal berikut:

\section{a. Peletakan Visi Madrasah Diniyah}

Dalam menentukan visi madrasah diniyah, harus ditentukan 'filter madrasah yang memiliki orientasi: 1) menarik komitmen dan menggerakkan orang; 2) menciptakan makna bagi kehidupan anggota organisasi madrasah diniyah; 3) menciptakan standar unggulan; 4) menjembatani keadaan sekarang dan keadaan masa depan. Adapun dasar-dasar perumusan visi madrasah hendaknya tidak terlepas dari beberapa pertimbangan pokok berikut ini : 1) mencerminkan apa yang ingin dicapai madrasah diniyah; 2) mempunyai arah dan fokus strategi yang jelas; 3) mampu untuk mengekplorasi kesempatan dan tantangan madrasah diniyah; 4) mampu menjadi perekat dan menyatukan berbagai gagasan strategi yang terdapat dalam madrasah sebagai sebuah organisasi; 5) memiliki orientasi terhadap masa depan; 6) mampu menumbuhkan komitmen seluruh jajaran dalam lingkungan madrasah; 7) mampu menjamin kesinambungan kepemimpinan organisasi madrasah. ${ }^{26}$

\section{b. Pemantapan Misi Madrasah Diniyah}

Misi merupakan suatu yang harus dilaksanakan oleh pilar manajemen agar tujuan organisasi dapat terlaksana dan berhasil dengan baik. Dengan adanya misi tersebut diharapkan seluruh komponen organisasi mampu memahami peran dan program sasaran serta hasil yang akan diperoleh organisasi di masa mendatang. Dengan misi diharapkan pula bahwa pelaksanaan program dapat dilaksanakan secara terarah, tepat dan cepat. Oleh karena itu perumusan misi madrasah diniyah harus dilakukan dengan : 1) melibatkan pihak yang terkait; 2) menilai lingkungan, terkait dengan tingkat kelayakan, varian kepentingan (conflicts of interest), dan kondisi lingkungan; 3) menyelaraskan kegiatan, proses utama, dan sumberdaya.

Adapun yang perlu diperhatikan dalam perumusan misi madrasah adalah : 1) produk/pelayanan yang ditawarkan; 2) tingkat kebutuhan dan ketertarikan masyarakat; 3) sasaran publik mana yang akan dilayani, terutama untuk

${ }^{25}$ Dalam Fatah Syukur. Manajemen Pendidikan Berbasis pada Madrasah.(Semarang: Pustaka RIzki Putra. 2011), 201-202

${ }^{26}$ Haedari Amin, 30 
menentukan madrasah perkotaan dan pedesaan; 4) kualitas produk madrasah yang memiliki daya saing; 5 ) aspirasi yang diinginkan di masa depan.

\section{c. Perumusan Tujuan Madrasah Diniyah}

Ada beberapa hal pokok yang perlu diperhatikan dalam upaya merumuskan tujuan dari dilaksanakannya suatu program, termasuk juga tujuan didirikannya madrasah diniyah. Hal ini antara lain : 1) kondisi jangka waktu; 2) tujuan dapat diformulasikan secara berjenjang; tingkat organisasi madrasah-tingkat program madrasah sub-program madrasah; 3) perhatian terhadap isu penting terutama dalam upaya memfokuskan pada hal yang lebih diprioritaskan.

Di samping itu perlu juga dilakukan pengujian terhadap rumusan tujuan yang telah ditetapkan, hal ini karena setidaknya tujuan itu telah memenuhi kriteria sebagai berikut : 1) tujuan harus selaras dan merupakan jabaran dari visi, misi, dan prinsip-prinsip madrasah; 2) memberikan kontribusi pada pencapaian misi, program, dan sub program madrasah; 3) tujuan yang diprioritaskan berdasarkan kebutuhan internal/eksternal; 4) tujuan tidak akan berubah hingga terjadinya perubahan lingkungan yang menimbuilkan masalah; 5) tujuan umumnya mencakup suatu periode waktu yang relatif lama.

\section{d. Menetapkan Sasaran Madrasah}

Sasaran merupakan tujuan dalam batas-batas yang spesifik terukur, yaitu sesuatu yang akan dicapai / dihasilkan secara nyata. Biasanya ditentukan dalam wujud jangka waktu: setahun atau triwulan. Dalam hal ini, sasaran lebih spesifik daripada tujuan atau bagian untuk mencapai tujuan, serta dibatasi waktu tertentu. Beberapa hal yang harus diperhatikan dalam menetapkan sasaran adalah : harus spesifik, measurable, aggressive but sustainable, result oriented, dan time-bound. ${ }^{27}$

\section{e. Peningkatan Mutu Pengelolaan Madrasah Diniyah}

Dalam peningkatan mutu madrasah, ada empat teknik yang dapat diaplikasikan: 1) school review atau madrasah review, 2) benchmarking, 3) quality assurance, dan 4) quality control. ${ }^{28}$ Keempat teknik tersebut dapat dijelaskan sebagai berikut :

\section{a. School review}

Suatu proses dimana seluruh komponen madrasah bekerja sama khususnya dengan orang tua dan tenaga profesional (ahli) untuk mengevaluasi dan menilai efektivitas sekolah, serta mutu lulusan. School review dilakukan untuk menjawab pertanyaan berikut: 1 . Apakah yang dicapai sekolah sudah

\section{${ }^{27}$ Ibid, 33}

${ }^{28}$ Anonim.Manajemen Mutu Terpadu dalam Pendidikan/Kultur Sekolah, Depdiknas (hand out pelatihan calon kepala sekolah, Direktorat Sekolah lanjutan Pertama. 2000), 200-202

72 | FalASIFA, Vol. 9 Nomor 2 September 2018 
sesuai dengan harapan orang tua siswa dan siswa sendiri?; 2) Bagaimana prestasi siswa?; 3) Faktor apakah yang menghambat upaya untuk meningkatkan mutu?; 4) Apakah faktor-faktor pendukung yang dimiliki sekolah ?

School reviewakan menghasilkan rumusan tentang kelemahan-kelemahan, kelebihan-kelebihan dan prestasi siswa, serta rekomendasi untuk pengembangan program tahun mendatang.

b. Benchmarking :

Suatu kegiatan untuk menetapkan standar dan target yang akan dicapai dalam suatu periode tertentu. Benchmarkingdapat diaplikasikan untuk individu, kelompok ataupun lembaga.

Standar dapat ditentukan berdasarkan keadaan/ralitas yang ada di pesantren, misalnya prestasi yang diraih santri yang alim dan santri yang sedikit nakal namun cerdas (internal benchmarking), maupun membandingkan standard kualitas dari pesantern lain yang lebih baik (external benchmarking)

Tiga pertanyaan mendasar yang akan dijawab oleh benchmarking adalah: Seberapa baik kondisi kita?,Harus menjadi seberapa baik?, Bagaimana cara untuk mencapai yang baik tersebut?

Langkah-langkah yang dilaksanakan adalah: Tentukan fokus, Tentukan aspek/variabel atau indikator, Tentukan standard, Tentukan gap (kesenjangan) yang terjadi, Bandingkan standar dengan kita, Rencanakan target untuk mencapai standard, Rumuskan cara-cara program untuk mencapai target

\section{c. Quality assurance}

Suatu teknik untuk menentukan bahwa proses pendidikan telah berlangsung sebagaimana seharusnya. Dengan teknik ini akan dapat dideteksi adanya penyimpangan yang terjadi pada proses. Teknik menekankan pada monitoring yang berkesinambungan, dan melembaga, menjadi subsistem madrasah.

Quality assuranceakan menghasilkan informasi, yang: 1) Merupakan umpan balik bagi sekolah, 2) Memberikan jaminan bagi orang tua siswa bahwa sekolah senantiasa memberikan pelayanan terbaik bagi siswa.

Untuk melaksanakan quality assurance, maka sekolah harus :

1. Menekankan pada kualitas hasil belajar

2. Hasil kerja siswa dimonitor secara terus menerus

3. Informasi dan data dari sekolah dikumpulkan dan dianalisis untuk memperbaiki proses di sekolah.

4. Semua pihak mulai kepala sekolah, guru, pegawai administrasi, dan juga orang tua siswa harus memiliki komitmen untuk secara bersama 
mengevaluasi kondisi sekolah yang kritis dan berupaya untuk memperbaiki.

\section{d. Quality control}

Suatu sistem untuk mendeteksi terjadinya penyimpangan kualitas output yang tidak sesuai dengan standar. Oleh sebab itu Quality control memerlukan indikator kualitas yang jelas dan pasti, berdasarakan tipologi madrasah yang ada sehingga dapat ditentukan penyimpangan kualitas yang terjadi.Standar kualitas ini bersifat relatif dan dapat diciptakan oleh setiap pesantren.Standar kualitas dipergunakan sebagai tolok ukur untuk mengetahui maju mundurnya madrasah diniyah.

\section{KESIMPULAN}

Di era kontemporer ini manajemen mutu pengelolaan madrasah diniyah harus dikelola secara professional, terutama demi tetap eksisnya lembaga yang bercorak keagaamaan ini di masa yang akan datang, mengingat perkembangan ilmu pengetahuan dan teknologi serta tuntutan yang semakin komplek di zaman sekarang ini.Perlu adanya strategi pengelolaan yang dapat dikembangkan oleh para pengelola madrasah diniyah, dengan mengedepankan kreatifitasnya masingmasing sesuai dengan keadaan kultur masyarakat di sekitar madrasah diniyah tersebut.Pengelolaan madrasah diniyah perlu didukung oleh berbagai faktor, baik internal maupun eksternal seperti sumber daya manusianya, kebijakan pemerintah yang memberikan ruang gerak fleksibel, partisipasi, serta dukungan masyarakat, suasana lingkungan yang kondusif dan kompetitif, peran media massa dan lain sebagainya. Pengelolaan Madrasah Diniyah yang professional, dengan strategi yang bagus dan didukung oleh faktor internal dan eksternal diharapkan mampu memberikan output pendidikan yang berupa generasi-generasi millennials yang berakblakul karimah, berintelektual, memiliki ketrampilan dan beramal sholih sehingga mampu memberikan kontribusi terhadap kejayaan peradaban Islam, bangsa dan Negara Indonesia dimasa sekarang dan yang akan datang.

\section{DAFTAR PUSTAKA}

M. Ishom el Saha. 2005. Arah Pengembangan Madrasah Diniyah di Indonesia. Jurnal Mihrab, Edisi I, th. III Oktober 2005

Malik Fadjar. 1999. Madrasab \& Tantangan Modernitas, Mizan:Bandung Edward Sallis. 2006. Total Quality Management in Education. Jogjakarta; Ircisod, Bambang H. Hadiwiarjo,\& Sulistijarningsih Wibisono. 2000.Memasuki Pasar Internasional Dengan ISO 9000.Jakarta : Ghalia Indonesia

Departemen Agama RI II .2000. Pedoman Penyelenggaraan dan Pembinaan

74 | Falasifa, Vol. 9 Nomor 2 September 2018 
Madrasah Diniyah. Jakarta: Depag.

Departemen Agama. 2006. Draf penyelenggaraan Madrasah Diniyah. Jakarta:

Direktorat Pendidikan Diniyah dan Pesantren ditjen Pendidikan Islam

Depag RI

Dirjen Kelembagaan Agama Islam Depag.Manajemen Merbasis Madrasah

Amin Haedari, dkk. 2004, Peningkatan Mutu Terpadu Pesantren dan Madrasah

Diniyah, Jakarta; Diva Pustaka

Anonim, 2000.Manajemen Mutu Terpadu dalam Pendidikan/Kultur Sekolah,

Depdiknas, hand out pelatihan calon kepala sekolah, Direktorat Sekolah lanjutan Pertama.

A.W. Munawwir. 2002. Kamus Arab Indonesia.Surabaya: Pustaka Progresif.

Fatah Syukur, 2011. Manajemen Pendidikan Berbasis pada Madrasah. Semarang:

Pustaka RIzki Putra

Fatah Syukur. 2012. Sejarah Pendidikan Islam, Semarang: Pustaka Rizki Putra

Fatah Yasin. 2008. Dimensi-dimensi Pendidikan Islam, Malang: Sukses Offset.

Haidar Putra Daulay.2009. Sejarah Pertumbuban dan Pembaharuan Pendidikan Islam Indonesia. Jakarta: Kencana Predana Media Group

Haidar Putra Daulay. 2001. Historisitas dan Eksistensi: Pesantren Sekolah dan Madrasah. Yogyakarta: PT Tiara Wacana.

Koswara, Deni. 2014. Manajemen Pendidikan. Bandung: Alfabeta.

Mulyasa. 2009. Menjadi Kepala Sekolah Profesional. Bandung: Remaja Rosdakarya. Qomar, Mujamil. 2007. Manajemen Pendidikan Islam. Jakarta: Erlangga

Raharjo.2013. Pemberdayaan Madrasah Diniyah Dalam Mewujudkan Pendidikan Berbasis Masyarakat di Madrasah Diniyah "Miftahul Huda" Kabupaten Kendal.Semarang: IAIN Walisongo.

Ridwan Nasir, 2005. Mencari Tipologi Format Pendidikan Ideal Pondok Pesantren di Tengah Arus Perubahan, cetakan pertama, Yogyakarta: Pustaka Belajar.

Suwito, 2008.Sejarah Sosial Pendidikan Islam, Jakarta: kencana Predana Media Group. 
76 | FalASIFA, Vol. 9 Nomor 2 September 2018 